\title{
The soviet security services in Volyn in 1944-1947
}

Summary: history of the Soviet secret police in Volyn is a perfect example to illustrate the main problems of Soviet power in controlling the newly incorporated and also hostile to the USSR territory. On the one hand, we are dealing with an extremely efficient reproduction of power structures, but on the other hand we are dealing with a shortage and an exceptionally poor quality of personnel forming the new system. An early preparation of foundations of the new administration and managerial personnel had been largely nullified after the arrival in Volyn. For the Soviet secret police, this situation is perfectly noticeable both in their structure, and also in temporary efforts of the authority aiming at rescuing plans which are falling apart. In contrast to earlier liberated eastern districts of Ukraine by the Red Army, where the reconstruction of prewar structures did not encounter with resistance, Volyn was an extremely difficult and dangerous area. As far as the District Departments of the NKVD and NKGB formed on the east freely develop their activities and had no major problems with the reconstruction of departments and sections standing lower in the organizational hierarchy, so in Volyn even the best trained and experienced commanders were not able to perform their tasks without the adequate preparation of regular officials. In order to find a remedy for the dramatic shortage of personnel in the ranks of the Soviet secret police former partisans were massively conscripted, and local residents formed additional Destructive Troops.

Keywords: Soviet secret police in Volyn, NKVD, NKGB, Volyn, World War II, underground movement in Volyn,

World War II brought unprecedented disruption to the historical continuity of the borderlands of East Central Europe. As a result, the post-war history of Volyn remains a black hole in Polish historiography. The lack of knowledge on aspects of the contemporary history of what, for many centuries, was one of the most important parts of Poland, is so significant that researchers in this subject area have to 
work from scratch - by determining the basic facts and mainsprings of the processes and changes that occurred there.

To properly understand Volyn's subjection to Sovietization, a process which was resumed in 1944 (after the initial annexation of Volyn under the terms of the Ribbentrop-Molotov Pact of 1939), it is essential to familiarize oneself with the techniques of the secret police operating in that region. The Chekists made it possible not only to fight the nationalist underground movement but also to complete the de-Polonization process started in 1939 and force the indigenous population to accept foreign norms and ways. In the popular perception, the Soviet secret police is associated with a smooth-running machine that only spelt violent repressions and ruthlessly crushed any symptoms of resistance to Soviet rule - "the only legitimate power". But deeper research into the archives and subject literature yields a totally different picture to the one that has come to prevail in Polish and Ukrainian historiography of recent years. The aim of this article is not to plead for or against the Soviet services but to fill a major gap in basic knowledge, and base interpretations on the full picture and not just select sources. Besides a detailed presentation of security service organizational structures, staff numbers and operating methods, I will try to expose its internal problems that have been shrouded in secrecy for many decades.

The source documents for the history of the Soviet security services are stored in the Security Service Department Archives in Kiev, Ukraine, but there are also published declassified records from Ukrainian and Russian archives, e.g. Osobyje papki Stalina I Mołotowa pro nacjonalno-wyzwolnu borotbu w Zachidnij Ukraini u 1944-1948 rr ${ }^{1}$, Ukrainskij Zdwych ${ }^{2}$, and Deset buremnych lit ${ }^{3}$ by W. Sehryjczuk, or a collection published in Russia: NKVD-MWD SSSR $v$ borbie s banditizmom $i$ vooruzonnym nacjonalistycznym podpoliem na zapadnij Ukrainie v zapadnoj Biełorusii i Pribaltikie 1939-1956. ${ }^{4}$

While the literature on Volyn's post-war history is in exceptionally abundant supply, the history of the Soviet security services operating in that area remains to be fleshed out. A few monographs, such as Narys istorii organiw wnutrisznych spraw Wotyni ${ }^{5}$, which deals with the militia, focus on miscellaneous narrow issues. Numerous studies on the terror and repressions that were unleashed in western Ukraine, such as Reabilitowani Istorieijej ${ }^{6}$, are devoted to the victims of the Chekists and not to an analysis of the power structures and operating methods

1 Osobyje papki Stalina i Mołotowa pro nacjonalno-wyzwolnu borotbu w Zachidnij Ukraini u 19441948 rr, Lviv 2010.

2 W. Serhyjczuk, Ukrainskij Zdwych, vol. III, Volyn, Kiev 2005.

3 W. Serhyjczuk, Deset buremnych lit, zachodnio ukrainski zemli u 1944-1953 rr. Nowi dokumenty i materialy, Kiev 1998.

4 NKVD-MWD SSSR $w$ borbie s banditizmom $i$ wooruzonnym nacjonalistycznym podpoliem na zapadnij Ukrainie, w zapadnoj Biełorusii i Pribaltikie 1939-1956, ed. by N.I. Władymircew, A.I. Kokurin, Moscow 2008.

5 Narys Istorii Orhaniw Wnutrisznych Spraw Wolyni, Luck (Lutsk) 2004.

6 Rehabilitowani Istoriej, Wołyńska Obłast, vol. I and III, Lutsk 2010, Rehabilitowani Istoriej Riwnenska Obłast, vol. I and III, Rivne 2006. 
of the authorities. Otherwise, the historical literature focuses only on the struggle between the Chekists and the Organization of Ukrainian Nationalists [OUN]. Of the wealth of monographs on this issue, one should mention the outstanding works of Dmitrij Viedienijev and Giendaij Bistruchin ${ }^{7}$, and the anti-UPA but professionally produced collection of studies, particularly on military aspects, entitled OUN-UPA protiv kogo vojevali ${ }^{8}$ issued in Sebastopol.

Both source documents and subject literature require very careful analysis. The accessible documents, in their majority, comprise reports on the situation in the field. At first glance, they offer few hard and fast general conclusions - just some eyeopening statistics on the number of arrests, the amounts of captured weapons, the numbers of enlisted agents. What should be remembered is that reports that passed muster were often the vehicles to career success and further promotion. Because of that, these types of documents require cautious analysis and juxtaposition with other sources. The recommendations made in the Resolutions of the $\mathrm{CK} \mathrm{KP}(\mathrm{b}) \mathrm{U}$, ordering the removal of irregularities in the functioning of the authorities, are very valuable here. A valuable supplement to the archives are reminiscences and accounts regarding many issues that could never find their way into official documents.

Unfortunately, the subject literature grossly overstates the struggle between the secret police and the UPA [Ukrainian Insurgent Army] which totally distorts not only the portrait of the epoch but also the importance of the security services. The history has carried over into current politics and the dispute over the historical vision of Ukraine. On the one hand, numerous authors, rooted in nationalism, unabashedly glorify the actions of the UPA ignoring or justifying its crimes. On the other hand, researchers from eastern and southern Ukraine present the Chekists as knights in shining armour trying to destroy fascism. Most Polish readers find this conflict baffling. Both sides gladly describe crimes committed by opponents while ignoring the track records of their own heroes. The subjective selection of documents or manipulation with quotations which are easy to verify, is commonplace. Trying to be objective, one should analyze all available documents while bearing in mind that the Soviet security services, apart from their notoriously repressive practices, their countless crimes and their outrageous abuses of power and authority, also fought banditry, caught war criminals and carried out a great variety of public administrative duties.

\section{Structure of the security services}

Comprehending the structure and division of duties in the Soviet security services is a challenge not only to the informed general reader but also to the professional

7 G. Bistruchin, D. Wiedienieew, Powstanska rozvidka dije tocno i vidvazno - dokumentalna spadscyna pidrozdiliv specjalnego naznacennja OUN ta UPA 1940-1950 roky, Kiev 2008.

8 Oun UPA. S kiem i protiw kogo oni wojowali. Istoryko-dokumentalnyje oczerni, ed. W.W. Woroncow, Sebastopol 2011. 
researcher. Many reforms, name changes and staff transfers ranging from individuals to entire departments, make it difficult to track and pin down the division of power and other inter-relationships. Another problem is that it is difficult to translate some Ukrainian and Russian terms into Polish. The translation of officer ranks and ministries is no problem, but some terms e.g. Operoupolnomoczenyj or differences in the terminology used by particular divisions, may require descriptive translations together with detailed footnotes. ${ }^{9}$

Before attempting to describe particular services and organizational structures, a brief look at the history and development of the Soviet security services during World War II might be in order. After Germany attacked the USSR in 1941, the People's Commissariat for Internal Affairs [NKVD] and the People's Commissariat for State Security $[N K G B]$ were merged, taking the name NKVD. Its high degree of centralization and focus only on the fight for survival of the Soviet Union, made it easier to manage the department. However, the changing situation on the front, heralded with the Red Army's recovery of the initiative, triggered another great reform of the security services in 1943. The necessity to mount offensive actions and conduct an increasingly proactive foreign policy, led to over-centralization becoming a problem. On April 14th 1943, the NKVD was divided again into two separate People's Commisariats - one for Internal Affairs under Lawrentij Beria and one for State Security under Vsevolod Merkulov. The duties of the newly formed NKGB comprised: intelligence work abroad, combating foreign intelligence operations in the USSR (which came in addition to military counterintelligence), countering anti-Soviet activities and protecting the Party leadership and the state. The Internal Troops and Anti-Banditry Departments ${ }^{10}$ that dealt with clandestine agencies, remained part of the NKVD. The decentralization process was to continue. On April 21st 1943, SMERSH - the Main Directorate of Counter-Intelligence, was formed out of Red Army Special Divisions. Its role was to neutralize foreign intelligence, counteract anti-Soviet activities or to infiltrate to the highest degree possible the ranks of those returning from prisoner-of-war camps or who broke through enemy encirclements. ${ }^{11}$ In Volyn, SMERSH played more of an incidental role because its officers were concentrated on following in the wake of the advancing front. The activities of the NKGB - MGB [MGB Ministry for State Security] in the initial period of imposing Soviet rule, especially in the struggle with the underground movement, languished in the shadow of the NKVD's operational initiatives.

9 There are no unambiguous equivalents to professional Russian/Ukrainian terminology in Polish, that is why, it is necessary to use descriptive translation or give the precise meaning of Polish equivalents.

10 The nomenclature of individual levels in the hierarchy of the secret police requires detailed description. As from 1946, the People's Commissariats had District Boards. They included particular Divisions divided into sections and Regional Outposts (Departments) where particular sections also functioned.

11 J. Nazarow, o. Rosow, I. Gruszewskij, Borba sowietskich organow gosudarstwiennoj bezopasnosti iorganizacje ukraińskich nacjonalistow 1944-1945 gg Razgrom UPA, in Oun UPA, p. 252. 


\section{Services in Volyn}

The reconstruction of the security apparatus in Volyn was based mainly on the experience gained in 1939-1941. The proper structures and managerial personnel of the District Boards of the NKVD and the NKGB were ready to operate long before assuming control of the territory won by the Red Army. Volyn was no exception; the Chekists got to work right away after taking over Lutsk and Rivne. Władymir Matwiejewicz Trubnikow ${ }^{12}$ was appointed the Commander of Rivne's NKVD, and O.M. Jakowenko ${ }^{13}$ of Volyn's. The NKGB chief in Volyn was Aleksander Nikołajewicz Martynow ${ }^{14}$ (until October 9th 1944).

Given their scope of duties, the Boards of the NKVD/MWD [MWD - Ministry of the Interior] were the most highly developed in terms of staff numbers and organizational structures. They also played a significant role in the immediate post-war years in Volyn.

Table 1. The structure of the NKVD District Board.

\begin{tabular}{|l|l|}
\hline $\begin{array}{l}\text { THE CHIEF OF THE NKVD CIRCUIT BOARD } \\
\text { Secretariat }\end{array}$ & DEPARTMENT OF FIRE-PROTECTION \\
\hline $\begin{array}{l}\text { DEPARTMENT OF MILITIA } \\
\text { The chief of the Militia fulfilled the duties of the } \\
\text { chief of the Circuit Board }\end{array}$ & DEPARTMENT OF ROADS \\
\hline DEPARTMENT OF BATTLE AGAINST BANDITRY & DEPARTMENT OF STATE'S ARCHIVES \\
\hline DEPARTMENT OF PRISON SYSTEM &
\end{tabular}

12 Trubnikow Władimir Matwiejewicz, born in 1907, NKVD officer, in the secret police since 1934, from 1938 to 1939 deputy and then People's Commissar of the Interior of the Moldova SSR. From 1939 the chief of the NKVD District Boards in Zhytomyr Oblast and Chernihiv Oblast. After the outbreak of the German-Soviet war, he was the chief of the 40th Special Division of the Army, then deputy chief of the Board of Southern and Voronezh Front Rear Protection, from January to August 1943 the Chief of the NKVD Board in Arkhangelsk Oblast. From August 11th 1943 to September 1944 the Chief of the NKVD in Rivne Oblast, then transferred to an equivalent post to Lviv where he worked until 1948. From 1948 to 1949 he was the Minister of Interior of the Kirghiz SSR. He served at various posts in the MWD until 1953. On December 14th 1953 he was downgraded and disciplinarily dismissed from the secret police. [Biographical note taken from the database of the Memoriat association, www.memo.ru/history/NKVD/kto/biogr/. Retrived on October 13th 2011].

13 O.M. Jakowenko, born in 1908, NKVD officer, delegate of the USSR Council, 1944 - 1948 the commander of the NKVD/MWD Board of the Volyn Oblast, then transferred to an equivalent post in Odessa, retired in 1952, awarded the title: Distinguished Worker of the NKVD. Narys Orhaniw, p. 79.

14 Aleksander Nikołajewicz Martynow, born in 1908, in the secret police since 1935, the Chief of the NKVD Board in Zhytomyr and Chernivtsi Oblasts 1939-1941, during the Soviet-German war held function in special departments of the fronts: Voronezh, Steppeand Ukrainian. From January to September 1944 the Chief of the NKGB in Volyn Oblast, then in Nikolayevsk, Odessa, Dnipropetrovsk and Zaporizhia. Retired in 1961, died in 1964. [Biographical note taken from the database of the Memoriał association, www.memo.ru/history/NKVD/kto/biogr/. Retrieved on October 13th 2011]. 


\begin{tabular}{|l|l|}
\hline DEPARTMENT OF LABOUR-CAMPS AND COLONIES & DEPARTMENT OF FIGHT AGAINST ORPHANHOOD \\
\hline DEPARTMENT OF PRISONERS AND INTERNEES & $\begin{array}{l}\text { DEPARTMENT OF LOCAL ANTI-AIRCRAFT } \\
\text { PROTECTION }\end{array}$ \\
\hline $\begin{array}{l}\text { SPECIAL DEPARTMENT I } \\
\text { Operational - internal NKVD investigation work }\end{array}$ & DEPARTMENT OF GOVERNMENT COMMUNICATION \\
\hline $\begin{array}{l}\text { SPECIAL DEPARTMENT II } \\
\text { Operational-investigation work of the Militia }\end{array}$ & DEPARTMENT OF PERSONNEL \\
\hline $\begin{array}{l}\text { DEPARTMENT OF COUNTER-INTELLIGENCE SMERSH } \\
\text { to work inside military units }\end{array}$ & DEPARTMENT OF FINANCE \\
\hline INSPECTION OF TRANSPORT MILITIA & DEPARTMENT OF ADMINISTRATION \\
\hline
\end{tabular}

Source: O. Szuszczuk, "Radianska karalno-represywna systema 1944 - 1953 - za materiałami Wołynskoj Oblasti", typescript of a dissertation, Library of the Lesya Ukrainka University in Lutsk, pp. 205-206.

The majority of the NKVD/MWD departments were of an administrative nature aimed at ensuring that the state authorities worked efficiently - see: the Department of Government Communication. There were 2361 NKVD officers and employees occupying managerial and operational posts in western Ukraine in 1945. Earlier, it was planned to engage 2661 employees, so the $86.6 \%$ success rate was quite a good result. A similar percentage of posts was achieved in the Militia, where it had been assumed that 5655 officers would be recruited. In the Volyn Oblast, of the 363 posts available for operational workers, 338 were filled. ${ }^{15}$

\section{The Militia}

As the Red Army progressed and conquered further territories, the authorities started to organize an administrative network. Its hub was the Militia. The ravages of war caused a telling shortage of well-qualified personnel, hence many officers had no theoretical knowledge or practical experience of police work. Managerial posts were given to experienced Chekists delegated from Ukraine's eastern and central oblasts, but rank-and-file civil and military personnel was drawn from "trusted" local residents. Partisan officers ${ }^{16}$ who served in 1939-1941, were willingly accepted into the Militia. They were familiar with the area and they had served in the Red Army, NKVD Interior Forces and Border Units of the NKVD. They were often convalescents unfit for front-line duty. There were also civilians among the enlisted officers

15 G. Bistruchin, D. Wiedienieew, Dwobij, pp. 264-265.

16 The ranks of the NKVD, especially of the Militia, were reinforced by partisans: Regulation CK KP (b) of February 15th 1944. CDAGOU (Centralnyj Derzawnyj Archiw Hromadskych Objendan Ukrainy - State Central Archives of Ukrainian Social Organizations) z. 1, op. 16, vol. 26, c. 13-14. Quote: Reabilitowani Istoriej, Wołynska Obłast, vol. 1, p. 211. 
who were delegated by the Party and Komsomol. ${ }^{17}$ The majority of the Militia's officers were sent in from numerous far-flung oblasts into western Ukraine. Because of their experience, they held mainly managerial posts.

As an organization to support the Militia in the field, civil-defense groups were formed out of local residents. In contrast to subordinate Liquidation Battalions, their role was only to protect village councils, kolkhozs, patrol the fields and gather information about the situation and attitudes in the villages. The civil-defense groups were controlled by district constables; one constable was usually responsible for two villages. ${ }^{18}$ A district constable's duties were mainly to control the situation in the field and report back to his supervisor. Because of poor training, they were unable to support operational initiatives effectively. Very often, they fell prey to nationalists because while being alone they had little chance of survival. ${ }^{19}$

Even mass recruitment was insufficient to meet the personnel needs of the Militia. It had a negative effect on the intellectual and moral level of the whole formation. The majority of officers, especially those who suffered severe injuries at the front, had serious psychological problems and often could not cope in their new environment. ${ }^{20}$ The situation with former Soviet partisans was even worse. They were used to stealing from local residents and resorting to thoughtless violence during in the subjugation phase. Very often, there were situations, e.g. in Rivne Oblast, where 30 partisans delegated to the Regional Department of the NKVD were ordered to gain food from "trofieje"21 - goods stolen from local residents. It was unfortunate for Volyn's residents that such people were the only representatives of authority. The future well-being of people and many villages depended on them. The problem of lack of personnel remained unsolved until the 1950s. It was estimated that in the late 1940s, only half of the vacancies were filled - especially at the lower levels. The situation was even worse because of losses inflicted by the OUN and armed assault bands. An additional problem was the age and health condition of many officers. ${ }^{22}$

Apart from staff shortages and truly low levels of intelligence in the Militia as a whole, most of the lower rank officers were known to drink on duty. The problem became especially difficult during the partisan war in Volyn. Official reports are full of descriptions of crimes committed by drunken officers. In the first quarter of 1945 in Volyn and Rivne Oblasts, of the seventy one proceedings commenced against militiamen, forty six related to offences and crimes committed under the influence of alcohol. ${ }^{23}$

17 W.W. Kowalyk, Poruszenia zakonnosti praciwnykamy NKS-MWS ta inszych prawoochronnych struktur na terenach stanislawskoj obłasti w perszi powojenni roky (1945-1947). Pryczyny i naslidky, Istorija Milicji Ukrainy. Mynułe i Suczasne - Zbirnyk Naukowych prac za Materiały I wseukrainskoj naukowoj konferencji, Stanyslaviv 2008, p. 40.

18 Rehabilitowani Istoriej, Wołynska Obłast, vol. 1, p. 82.

19 G. Bistruchin, D. Wiedienieew, Dwobij, p. 266.

20 W.W. Kowalyk, op. cit., p. 40.

21 Rehabilitowani Istoriej Riwnenska Oblast, p. 51.

22 Narys istorii organiw, p. 79.

23 W.W. Kowalyk, op. cit., p. 41. 
It is worth quoting an extract from the CK KP (b) bulletin, issue 36, on law and order violations in the Volyn Oblast:

In Lachowo village in the Poryck region, the Militia constable Worotnikow, having received an assignment from the chief of RONKVD to arrest citizen Parafieniuk, who allegedly deserted from the Red Army, together with 4 soldiers from the public protection group, surrounded the house of citizen Parfieniuk between 8 and 9 p.m., went inside to "frighten" (the wife) and shot dead her daughter with a sub-machine gun. In order to hide the crime, Worotnikow also shot citizen Parfeniuk, her 15-year old son, her second daughter and a 3-month old baby. During the investigation it was determined that citizen Parfieniuk was serving in the Red Army and had never deserted.

In the village Varenchyno Isajew, the Chief of Osiutyshesk RO NKVD, and officer Szejko, when drunk, opened fire on people who were gathering in the Village Council. Later, in the rooms of the Village Council, they organized the interrogation of citizen Maria Saweniuk (born in 1924) - the Secretatry of the Village Council. She was accused of stealing a machine gun. During the interrogation, Isajew and Szejko severely battered citizen Saweniuk, abused her by suggesting that she should kill the local Orthodox priest in proof of her innocence. After that, they undressed her beaten and dripping with blood and took her out of the Village Council and put under guard in view of the local people. ${ }^{24}$

Crimes against civilians were most often committed in the course of armed antiunderground movement operations. Here is a fragment of a report on the situation in Rivne Oblast:

On the night of October 30th 1944, a group of Mlyniv RO NKVD officers under the command of senior militiaman Szwab and constable Klimenko were sent to the village of Smordwa. They were to establish if the (Orthodox) priest, Prybytowski, was visited by bandits. After their arrival, instead of carrying out their task, the group approached the priest's house and started shooting at random. As a result, they set the barn on fire. Next, they went inside the priest's house where there was nobody apart from his family. They hit the priest a few times and smashed all the furniture. Not being sated with this, constable Klimenko and militiaman Szwab took the family outside: Fr. Prybytowski, his wife and 11-year old son, his 70-year old father and daughter. They made them kneel before the burning barn and during this time they took their clothes and valuables. After humiliating them thus, constable Klimenko took the priest and killed him. Klimenko and Szwab were arrested and taken to court.

Berdnikow, the ex-chief of Morochynovski RU NKGB was continually drunk and encouraged regional division officers to drink. He also had contacts with people investigated for speaking out against the Soviets and drank with them. While being under the influence of alcohol, Berdnikow killed the Chairman of the Muravynsk Village Council of Kovaltshyn [...].

24 An extract from CK KP (b) U information bulletin issue 36 dedicated to violations of the law in Volyn Oblast, CDAGOU z. 1 op. 23, vol. 1390, k. 1-3, [in:] W. Sehryjczuk, Ukrainskij Zdwyh, p. 495. 
On December 7th 1944, in the course of eliminating a band in the village of Horbyn in the Ostroh region, citizen Ustymczuk Mokrina Józefówna was arrested. As was established later, Ustymczuk was the mother of 11 children (3 sons served in the Red Army, her husband worked in the defense industry). She was arrested and transferred to RO NKVD. The Chief of RO NKVD, senior militia lieutenant Pikanow, while in a drunken state, on the same day, without analyzing the case, ordered Łogiwenko, an NKVD soldier, to take Ustymczuk into the bushes near the post office (in the town center of Ostrozyc) and execute her. Łogiwenko obeyed the order. During the investigation it turned out that Ustymczuk had not had any connections with UON-UPA. Pikanow was suspended and put before a court martial [...]. ${ }^{25}$

The victims of inebriated militiamen were often other officers. One of the most peculiar and at the same time tragic mistakes took place in Holoba. On April 4th 1947, a special three-man operational group from Liuboml arrived at the Regional Executive Committee. Their task was to arrest four clerks suspected of corruption and fraud. It was feared that there could be a leak of information about the arrest, so not even the local Militia and MGB were informed about it. Unfortunately, it turned out that the militiamen under the command of lieutenant Niesłuzow were drunk. Upon entering, they demanded to see the documents but they were taken for bandits. The panic-struck clerks managed to escape through the windows and get to the militia station where they reported an assault. After raising the alarm at the local MWD and MGB, the building was surrounded. The inebriated officers from Liuboml opened fire on their colleagues and killed constable Chrapow who was sent there only to examine the situation. Three people were killed and one injured during that shoot-out. ${ }^{26}$

The helpless situation that many officers found themselves in can be put down to drunkenness and violence towards local residents. At small stations, militiamen were defenseless against UPA units and they were the ones who sustained the greatest losses of all the NKVD/NKGB forces. Stress induced by constant danger and brutal murders of militiamen committed by nationalists, were caused by the escalation of violence and more frequent use of guns - not least in unjustified situations. As a result, people were afraid of militiamen. Even party officials admitted that when they appeared in the company of NKVD officers, they aroused fear and hatred. ${ }^{27}$

In 1946, the number of violations of "Soviet law and order" and crimes committed by militiamen, increased in comparison to previous years. In the whole Ukrainian SSR, $30 \%$ of penal proceedings against officers concerned grievous crimes ${ }^{28}$ and over half took place /in the western oblasts of the country. According to Igor Nikołajew who analyzed the incidence of sanctions against NKVD/NKGB officers, between the 1930s and the 1950s,

25 The report on the struggle with Ukrainian-German nationalist bands in Rivne Oblast conducted by NKVD and NKGB bodies, NKVD Internal Troops, CDAGOU z. 1, op. 23, vol. 1700, k. 69-78 [in:] W. Sehryjczuk, Ukrainskij Zdwyh, pp. 502-503.

26 A report on evidence of banditry in Volyn Oblast, GDA, SBU (Department Archives of Ukraine's Security Service - Hałuzewnyj Derżawnyj Archiw Służby Bezpeky Ukrainy) z. 2, op. 91, vol. 8, k.154-157.

27 Rehabilitowani Istoriej Riwneska Oblast, p. 49.

28 W.W. Kowalyk, op. cit., p. 41. 
almost all of the disciplinary and criminal cases initiated against officers were justified and, unlike cases from the 1930s, they did not have the nature of politically motivated repressions. Those cases were about justice for real crimes and offences committed while on duty. ${ }^{29}$

Most cases regarding the abuse of power were investigated disciplinarily. Inspections in the Militia showed that the most common forms of abuse were unlawful arrest and violent assault. Such cases often ended with a warning, reprimand or several days' detention. Only the most drastic cases of murder, robbery and sexual offences were taken to court. In dealing with such cases, the courts tended to disregard the principle of equal justice for all and tried to find extenuating circumstances such as distinguished service in combat, previous exemplary service record, young age or the necessity to obey orders. ${ }^{30}$ It is worth mentioning that for the Communist authorities, the primary and most important thing was the aim of taking hold of a given territory, while the measures taken to achieve that aim were of secondary importance.

The MWD command, besides punishing people who broke "Soviet law and order", tried to educate its personnel. There were evening classes for privates in Lutsk. The more talented officers were sent to attend specialist courses in criminology in Lviv, Kharkiv, Odessa and Chernivsti. ${ }^{31}$ Educating militiamen and more selective recruitment unfortunately were not enough to significantly change the situation. Internal disintegration caused by crime and alcoholism prevented the Militia from doing its basic job and, more often than not, discredited the Soviet authorities as a whole. In 1947 , there was a staff overhaul in the Militia which led to the removal of officers unfit for service. ${ }^{32}$ However, as later events were to suggest, that did not solve all the issues.

\section{Anti-Banditry Departments (OBB)}

The Soviet secret police units to fight underground and nationalist organizations were the Anti-Banditry Departments (OBB) which were a part of the NKVD. When changes were made in the structures of the secret police under the impact of the outbreak of the German-Soviet war, the OBB was separated from the Main Board of the Militia and raised to the status of an independent Department in that Office. The same structure was introduced at the Soviet Republic level. After the division of the People's Commissariats in 1943, the Anti-Banditry Departments remained part of the NKVD. In October 1944, the Anti-Banditry Department at the Soviet Republic level was transferred to the Board headed by lieutenant-general T.A. Strokacz. Strokacz also became a deputy of the Commissioner of People's Internal Affairs of the Ukrainian SSR. As of October 12th 1944, there were 1710 officers in the field and 23 in the central system in the Anti-Banditry Departments. ${ }^{33}$

29 I. Nikołajew, Represji proty wijskowosłużbowciw ta praciwnikiw organiw GPU - NKWS Ukrainy w 20-50 roky XX stolitija - Autoreferat Dysertacji, Kiev 2006, p.15.

30 W.W. Kowalyk, op. cit., p.41.

31 Narys istorii organiw, p. 83.

32 ibid, p. 83.

33 J. Nazarow, O. Rosow, op. cit., p. 41. 
Table 2. Internal division of the OBB

\begin{tabular}{|l|l|}
\hline UNIT I & identification of the OUN leadership and UPA staff \\
\hline UNIT II & detection and liquidation of underground forces in the Rivne, Volyn and Ternopil Oblasts \\
\hline UNIT III & $\begin{array}{l}\text { detection and liquidation of underground forces in the Lviv, Stanislaviv, Drohobych and } \\
\text { Chernivtsi Oblasts. }\end{array}$ \\
\hline UNIT IV & detection and liquidation of underground forces in eastern Ukraine \\
\hline
\end{tabular}

Source: J. Nazarow, O. Rosow, I. Gruszewskij, Borba, p. 253.

As events unfolded, the significance of the OBB was to rise. The most experienced and best Chekists were sent into the flashpoint areas and their ranks were constantly increased in support of secret police operations. In December 1944, the $\mathrm{OBB}$ was reorganized into the Main Board of Anti-Banditry Operations. The staff of the Liquidation Battalions was subordinated to it. ${ }^{34}$

Control over the coordination of operations in Volyn was taken by gen. Timofiej Strokacz. He was assigned help - the deputy of the People's Commissar of State Security of the USRR, Jesipenka, and the chief of the NKVD USRR internal troops, M.P. Marczenkow. ${ }^{35}$ Operational headquarters dedicated to fighting the underground movement was placed in Rivne.

In comparison with other NKVD departments, the OBB did not have to deal with so many problems as e.g. the Militia, but the abilities of some officers left much to be desired. The most interesting and accurate evaluation of the Chekists was given by their opponents - the OUN plants, whose everyday job was to fight the Soviet secret service from within. According to them, at the higher (Soviet Republic and district) levels, there were well-educated and intelligent professionals. The situation was completely different in the field where most officers were described as morons, brutes and careerists. ${ }^{36}$

With time, the number of OBB officers increased, especially because of the officers who were sent in from other oblasts of the USRR. In 1945, there were 48 officers in the Volyn unit of the OBB and 112 operational officers ${ }^{37}$ in regional outposts. There were more changes in the organization of the secret police structures at the beginning of 1947. By virtue of MWD-MGB USRR order no. 0074/0029 of January 21st 1947, the Anti-Banditry Departments subordinated to the MWD, together with all their civilian employees, were transferred to the MGB. ${ }^{38}$ This reform gave the ability

34 ibid, p.254.

35 ibid, p. 254.

36 S. Mudry-Mecznyk, Stużba bezpeky Rewolucijnoj OUN u Borotbi z NKVD-NKGB-MGB-MED., Termopil 1994, p.76.

37 G. Bistruchin, D. Wiedienieew, Dwobij, p. 266.

38 Joint MWD and MGB order no. 0074/0029 of January 21st 1947, GDA SBU z. 2, op. 91, vol. 2, k. 216. 
to focus one department on the struggle against the underground movement. This turned out to be a good move because it increased the involvement of the western intelligence service that used OUN outposts abroad to infiltrate Ukrainian territory. At the local level, this reform brought different effects: the MWD was no longer responsible for fighting the underground movement so it could focus more on fighting criminal activity. The inter-departmental transfer of the OBB left very interesting records regarding the structure and activity of the Chekists in particular areas. The report on the personnel, the secret service and the documents drawn up in 1947 on the transfer, constitutes a valuable source on the scope and capacities of the Soviet services. The reports drawn up by regional NKVD branches, are not uniform and include diverse details. In most cases, the commanders gave the number of full-time officers, the headcount of Liquidation Battalions and data regarding the variety of the secret services involved. Unfortunately, some reports are incomplete and others include information which, under the operating rules of the services, should not have been disclosed. A good example of this is a very detailed report from the Volodymyr region where the over-zealous commander gave a decoded list of his secret service units along with the pseudonyms and real names of his agents and informants. ${ }^{39}$

Table 3. Statistical data regarding the OBB and Liquidation Battalion operations in selected regions of Volyn. February 1947.

\begin{tabular}{|l|l|l|l|}
\hline REGION & $\begin{array}{l}\text { NUMBER OF FULL-TIME } \\
\text { OFFICERS }\end{array}$ & $\begin{array}{l}\text { NUMBER OF SOLDIERS } \\
\text { IN LIQUIDATION } \\
\text { BATALIONS }\end{array}$ & $\begin{array}{l}\text { SECRET SERVICE STAFF } \\
\text { NUMBERS }\end{array}$ \\
\hline Berestechko & 4 officers & 119 people in 12 units & $\begin{array}{l}88 \text { including } 37 \text { agents, } \\
51 \text { informants }\end{array}$ \\
\hline Horokhiv & -- & -- & $\begin{array}{l}190 \text { including } 1 \text { resident, } \\
95 \text { agents, } 94 \text { informants }\end{array}$ \\
\hline Holoby & 5 officers & 90 people in 14 units & \\
\hline Kamin Kashyrskyi & --- & -- & 143 people \\
\hline Kolky & 5 officers & 90 people in 10 units & $\begin{array}{l}147 \text { including } \\
132 \text { informants }\end{array}$ \\
\hline Kovel & 13 officers & 165 people in 10 units & 175 \\
\hline Liuboml & 3 officers & 240 people & 42 \\
\hline Lutsk & 5 officers & 285 people & 89 \\
\hline Olyka & 4 officers & 89 people in 5 units & 75 \\
\hline Ratne & 6 officers & 232 people in 14 units & 69 \\
\hline Teremne & --- & 109 people in 6 units & --- \\
\hline
\end{tabular}

39 Report on the transfer of Regional Department (Delegate Outpost) to Battle against Banditry from MWD to MGB, GDA SBU z. 2, op. 90, vol. 65, k. 59-64. 


\begin{tabular}{|l|l|l|l|}
\hline Volodymyr-Volynskyi & 6 officers & -- & $\begin{array}{l}170 \text { including } \\
4 \text { residents, } 4 \text { agents, } \\
162 \text { informants }\end{array}$ \\
\hline Zdolbuniv & 5 officers & 53 people & --- \\
\hline
\end{tabular}

Source: Reports on transfer of the Regional Departments (Outposts) of Anti-Banditry forces from the MWD to the MGB. ${ }^{40}$

A typical OBB comprised 5 officers usually led by a lieutenant. Apart from coordinating and leading Liquidation Battalion operations, the officers dealt with recruitment and liaison with the secret services. On average, one officer had 15 agents who were often simple informants. More valuable secret agents who were able to infiltrate the underground movement were allocated to the district secret police.

One of the most numerous departments was the Kovel RO MWD. It had 13 officers led by captain Sidaszenko. This number was due to not only the size of the city and the complexity of the situation in this region, but also the necessity to reinforce the security of the strategic railway junction (MWD/MGB transport units were responsible for the basic security of the railway).

Considering the above, the five-man unit in Lutsk seems quite insignificant. There were district and regional security forces operating there, but the peaceful situation there was the reason for their small number. As opposed to the provinces, the majority of Lutsk's residents were new arrivals not associated with nationalist activity.

After the transfer to the MGB, the OBB reinforced Board 2. On this basis, special $2 \mathrm{~N}$ Departments were set up which were to wage war on nationalism. There were also slight changes in the structure of the Departments.

Table 4. The structure of 2N Departments in western oblasts of the USSR in 1947.

\begin{tabular}{|l|l|}
\hline UNIT I & Identification of central and national OUN Directorates \\
\hline UNIT II & Operational-level initiatives against lower-ranking directorates in the field \\
\hline UNIT III & Fighting Melnyks and other nationalist organizations \\
\hline UNIT IV & Leading Liquidation Battalions and Secret-Service and Combat Groups \\
\hline UNIT V & Operational register, record gathering on members of the underground \\
\hline UNIT VI & Radio communication, operating personnel of "Triewoga"1 radio equipment \\
\hline
\end{tabular}

Source: G. Bistruchin, D. Wiedienieew, Dwobij, p. $270{ }^{41}$

40 Report on the transfer of the Regional Anti-Banditry Department (Outposts) from the MWD to the MGB in Volyn Oblast, GDA SBU z. 2, op.90, vol. 65, k. 14-337.

41 Small transmitters were carefully hidden in houses or places which members of underground could potentially visit. If they arrived, a trained agent would activate the device by pressing a camouflaged button. The radio signal was received by the regional MGB and operational groups would then be sent into this region. 
$2 \mathrm{~N}$ Departments operated until the creation of the KGB whereupon their duties were taken over by Board 4 dealing with nationalism. ${ }^{42}$

\section{The Internal Troops}

Keeping order in the areas taken over by the USSR was the main task of the Internal Troops who were the only ones capable of supporting the Militia and the NKGB.

Following the confusion of the first two years of the war, in 1943 the structure of the internal troops started to be adapted to the new circumstances. They were still responsible for protecting the fighting armies and the rearguard units tasked with stopping their own soldiers from retreating. An additional responsibility of the Internal Troops was to restore Soviet power in the areas recovered from the Germans. According to the Regulation of the Supreme Defense Committee of January 4th 1942 and the order of the Peoples' Commissar of the Interior of January 5th 1942, sub-units of the Internal Troops were to move in directly in the wake of the Red Army's offensive units and organize the most important objects and support the security services in fighting spies and saboteurs within 3-4 hours of liberating a town. They also organized patrols of the immediate vicinity, checked personal documents, set up road blocks, identified minefields and collected abandoned weapons and ammunition. ${ }^{43}$

What should be emphasized is that, on paper, the Internal Troops had securityenforcement duties, however, closer scrutiny suggests that proactive repression was their basic brief. ${ }^{44}$

The recovery of greater expanses of territories from the Germans triggered far-reaching changes. The aim was to prepare the Internal Troops to accomplish designated tasks in peacetime, e.g. to fight the anti-Soviet underground movement. The brigade's units 16 and 24 were the first to enter Volyn but because of the existing situation they proved insufficient. Transferring additional Internal Troop units to Volyn took almost 2 months. Finally, in March 1944, in Rivne Oblast alone, there were 73208 soldiers supported by 22 light T 70 tanks. ${ }^{45}$ But that did not last long because most of the Internal Troops constantly trod on the heels of the advancing front. According to the official records, in the summer of 1945, there were $34865^{46}$ soldiers in western Ukraine and until the end of the year this number fell to 22907.

42 G. Bistruchin, D. Wiedienieew, Dwobij, p. 273.

43 J. Nazarow, O. Rosow, I. Gruszewski, Borba, p. 247.

44 O. Kalkuk, Wijska NKWS (MWS) w Ukraini 1939-1953. historyko prawowyj aspekt, disertation abstract, Kiev 2006, p. 14.

45 Rehabilitowani Istoriej Riwnenska Oblast, vol. 1, p. 46.

46 I. Biłas, Represywno Karalna Systema w Ukraini 1917-1953, vol. 2, Kiev 1994, p. 498. 
Table 5. Units of the Internal Troops operating in Volyn in 1944-1945.

\begin{tabular}{|c|c|c|}
\hline UNIT & STATIONING REGION & DATES \\
\hline $\begin{array}{l}\text { Ordzhonikidze Rifle Division } \\
\text { Changed into Rifle Division } 9\end{array}$ & $\begin{array}{l}\text { Lutsk } \\
\text { Lutsk }\end{array}$ & \begin{tabular}{|l|}
23 III -13 III 1944 \\
9 XI - 31 XII 1944 \\
\end{tabular} \\
\hline $\begin{array}{l}\text { Shumsk Rifle Division } \\
\text { Changed into Rifle Division10 }\end{array}$ & \begin{tabular}{|l|} 
Sarny \\
Sarny
\end{tabular} & \begin{tabular}{|l|}
26 III - 13 IV 1944 \\
25 III $1944-6$ VI 1946 \\
\end{tabular} \\
\hline Rifle Brigade 16 & Sarny & I-III 1944 and VIII-X 1944 \\
\hline Rifle Brigade 18 & $\begin{array}{l}\text { Kiev - outgoing actions in Volyn } \\
\text { and Galicia }\end{array}$ & $10 \mathrm{VI}-31 \times 1944$ \\
\hline Rifle Brigade 20 & Kostopil, Kremenets & III-X 1944 \\
\hline Rifle Brigade 21 & Ostroh, Kopychyntsi & 24 III $1944-10$ X 1945 \\
\hline Rifle Brigade 24 & Rivne, Dubno & 2 III $1944-10$ X 1945 \\
\hline
\end{tabular}

Source: J. Nazarow, O. Rosow, I. Gruszewskij, Borba, p. 249.

Besides the units listed in this table, there were other forces operating in Volyn including the NKVD Railway Army ${ }^{47}$ (see: Supplement 1).

Frequent changes of personnel and units made verification difficult and caused various manipulations with the figures aimed at increasing the number of forces fighting the UPA. It should be noted that between January 1944 and December 1951 alone, about a hundred independent regiments, fifty independent battalions, two mobile groups and six trainee units were dispatched to western Ukraine. These forces never worked together, they just exchanged their locations. What is more, NKVD/MGB leaders treated the ongoing partisan warfare as an ideal military training ground for the up-and-coming next generation of Chekists. Students of the Leningrad, Moscow and Ordzhonikidze MWD schools, and those of the Moscow Finishing School for Frontier Army Officer ${ }^{48}$ joined the fight against the UPA.

During the transformation of the Peoples' Commissariats into Ministries, the Internal Troops were subordinated to the central unit of the MGB. ${ }^{49}$ It resulted in the Soviet Republic level MGB in Kiev taking control over all its republic-tier structures. However, the Internal Troops fully remained under Moscow's control. ${ }^{50}$ They were still used in oblasts and certain regions.

47 In October 1945,they had 1848 soldiers. A. Gogun, Diejatielnost woorużonnych nacjonalistyczieskich formirowaniuj na terytorii zapadnych oblastiej USSR 1943-1949, typescript of dissertation at www.oun-upa.org/ua/gogun. Retrieved on October 14th 2011.

48 J. Nazarow, O. Rosow, I. Gruszewskij, Borba, p. 249.

49 The transfer was on the joint MWD and MGB USSR order No. 0074/0029 of January 21st 1947. By virtue of this order, the Main Board of Internal Troops was created. These formations were to have a total of 68582 full-time soldiers, A.I. Kokurin, N.W. Pietrow, Łubiankia - WCZK, OGPU, KWD, NKGB, MGB, MWD, KGB 1917-1960. Sprawocznik, p. 37.

50 O. Kalkuj, op. cit., p. 14, 


\section{The Frontier Armies}

Once the Red Army reached the new borders, the USSR started to form the Frontier Army. Forty four units were formed by the end of 1944, and they were subordinate to the oblasts of the Ukrainian SRR. ${ }^{11}$ Officially, the new borders of the USSR in 1944 were still temporary, but it did not stop the Soviet Frontier Armies from reinforcing them. According to special instructions on how to protect the Polish frontier zone, frontier officers were supposed to fight armed nationalist units with all possible means including hot pursuit over the Polish border. ${ }^{52}$ In the frontier zone, the Frontier Armies, apart from their standard border protection duties, were used in the same way as the Internal Troops. Most of the skirmishes with the underground movement took place on the border itself especially during the attempts of UPA units to cross over from Poland to the USSR.

\section{Liquidation Battalions}

Another type of force used to fight the underground movement were the NKVD Liquidation Battalions. Their members were ex-partisans and local residents. Unfortunately, there is a dearth of materials on this topic in the archives and most of what is available is fragmentary and contains merely general information..$^{53}$

Liquidation Battalions, apart from protecting key objects, also served as hot pursuit units and Internal Troop reserves, which was especially useful when organizing large-scale blockades and raids. Liquidation Battalions were very often the only sizeable armed formation in a given area. Officers who were familiar with their areas also served as guides for Chekists and Internal Troop units. From the security service point of view, Istrebki (colloquially: members of that formation) were an ideal resource base for the recruitment of agents. Local NKVD officers were responsible for the organization of the battalions, but their low level of training was very often the reason for their shortcomings and failures. In theory, a member of a battalion had ten hours of training and political awareness classes per month, however, the general level of education and discipline was not satisfactory. In the evaluations of their superiors, local Polish officers had the best attitude and were the most disciplined. It was the only chance for them to protect themselves from the UPA and get justice for murdered members of their families. After the resettlement of the Polish population westwards, across the river Bug, only Ukrainians were left in the battalions. The battalions found useful support, when needed, in armed Party

51 The first and the strongest one was the Ukrainian Oblast, under the command of maj-gen P.W. Burmak. It consisted of Frontier Units no. 2, 88, 89, 90, 93, 98, 104. In autumn 1944, because of UPA activity, these forces were strengthened with the 42nd NKVD Motorized Regiment, a reserve frontier detachment and the 6th Air Regiment.

52 ibid, p. 249.

53 A good example is an article by Tomasz Balbus, Polskie "Istriebitielne bataliony" NKVD in 1944-1945, IPN Bulletin, no. 6 (17) June 2002, p. 74. 
activists who, by virtue of Regulation CK KPBU of May 10th 1944, in western Ukraine, received four thousand assorted weapons. ${ }^{54}$

Relations between the UPA and Liquidation Battalions were not always clearcut. Very often, their members and their families were brutally murdered by their adversaries, but sometimes, after the respective group members were disarmed, they would be released. Quite often, particularly in 1944, upon receiving their weapons, battalion units escaped to the forest. Gogun quotes a very interesting OUN-UPA pamphlet addressed to members of Liquidation Battalions in which it was argued that one of the NKVD's aims was to protect its own personnel and using Ukrainians to fight other Ukrainians who were described as obedient hunting dogs. ${ }^{55}$

\section{Coordination of the security forces}

At the beginning of the struggle with the underground movement, the Internal Troops took the leading role, although organizational divisions and lack of coordination between units led to the failure of many operations. Many a time, security service units fell into traps set by other units. An example of this would be a raid made by the 17th NKVD brigade at Novosilky in Rivne Oblast which intercepted an operational NKVD group from Dubne. ${ }^{56}$ Many such actions ended with an exchange of fire with officers and soldiers being killed. ${ }^{57}$

In 1945 and 1946 it was emphasized in official documents that there were poor communications between the NKVD and the NKGB. ${ }^{58}$ Because of repeated mistakes and mounting losses in the secret services, special groups of MWD USSR officers were dispatched to western oblasts of the USRR in May 1946. Their job was to investigate irregularities and help local secret police units. General Nikitinsky and colonel Prokofiejew, together with groups of officers, were dispatched, respectively, to Rivne and Lutsk. Their wide-ranging remits gave them control over almost all of the formations involved in fighting the underground movement. ${ }^{59}$

The situation improved a year later when western Ukraine was divided into operational regions corresponding to the administrative borders of the oblasts. Those were subordinate to operational groups that operated on the borders of particular administrative regions.

54 A. Gogun, op. cit.

55 ibid.

56 BTU F.P. Poticznoho (Library of Toronto University, Petra Poticznoho Collection) vol. 2. k. 83, [in:] W. Sehryjczuk, Ukrainskij Zdwych, pp. 483-485.

57 BTU F.P. Poticznoho, vol.6, k. 165-166 [in:] W. Sehryjczuk, Ukrainskij Zdwuch, pp. 464-465.

58 G. Bistruchin, D. Wiedienieew, Dwobij, p. 263.

59 Regulation of the Minister of the Interior of the USSR of May 13th 1946 on organizational undertakings aimed at supporting the fight with the OUN underground movement in western Ukrainian SRR oblasts, GARF (State Archive of Russian Federation - Gossudarstwiennyj Archiw Rossijsko Federacji) z. 9487, op. 1, vol. 521, k. 41-49 [in:] I. Biłas, op. cit., p. 632-637. 
Command over all operations was taken by triumvirates comprising: the MWD Commander of the District Department, the MGB chief of the District Department and the Internal Troops or Frontier Army commander based in the oblast. ${ }^{60}$ This system proved effective and ran smoothly until the conclusion of the struggle with the underground movement. Its working principles were dusted down and used half a century later in the war in Chechnya ${ }^{61}$

The basic factor that guaranteed the success of almost every security service operation - the system of gathering, processing and filing information - should not be overlooked in analyses in this field of historical research. The scarce availability of documents in this subject area makes the job of the researcher so much the harder, but it does not mean that the Soviet services did not compile databases. In 1944, the range of information about underground movement was quite poor and often erroneous, but in the following years, knowledge of particular underground activists was more accurate. The success in bringing about the final dissolution of the OUN was in many ways based on painstaking and inconspicuous information gathering.

\section{Summary}

The history of the Soviet security services in Volyn, perfectly illustrates the main problems of Soviet power in controlling the newly annexed territories that were hostile to the USSR. On the one hand, we are dealing with an extremely efficient reproduction of power structures, but on the other hand, we are dealing with staff shortages and exceptionally poor quality personnel making up the new system. The earlier preparatory foundations of the new administrative and managerial personnel largely fell apart upon its arrival in Volyn. This is clearly evident in the activities of the Soviet security services, both in their organizational structure, and in their ad hoc efforts to salvage their plans which invariably tended to fall apart. In contrast to the eastern districts of Ukraine which had been recovered earlier by the Red Army, where the reconstruction of prewar power structures did not encounter resistance, Volyn was an extremely difficult and dangerous area. Insofar as the District Departments of the NKVD and the NKGB in the east pursued their activities undisturbed and had no major problems with the reconstruction of local power structures, in Volyn even the best trained and experienced commanders were not able to perform their tasks without the support of adequately qualified staff. In order to remedy the dramatic shortage of personnel, former partisans were conscripted into the ranks of the Soviet security services, and local residents formed additional Liquidation Troops. Similarly, the emphasis in the Red Army was placed on the number of officials not on their quality. The enlistment of partisans on the one hand solved the problem of the number of officials and knowledge of the terrain, but, on

60 N. Plotnikow, Specsluzby borjutsa s terrorizmom, www.nvo.ng.ru (Niezawisimoje Wojennoje Obozrienije). Retrieved on February 16th 2001.

61 N. Plotnikow, op. cit. 
the other hand, it completely loosened discipline, and drastically reduced the level of efficiency of the whole secret service apparatus. It should be emphasized that the Soviet security services, especially the Militia, were often the only representatives of Soviet power in the field and became a symbol of a kind. As a result, it was not only Chekists, but also ordinary people dispatched from deeper inside the USSR to work in Volyn, who gave reasonable cause for fear and misgivings.

In the initial period of Soviet security service activities in Volyn, successes in combating the underground movement were achieved only due to the large number of officials and the impetus of the operations that this involved. The mass arrests and the concomitant primitive and brutal interrogation methods that were employed, sooner or later led investigators to people who really were connected with the underground movement, who, in turn, were handed over for further "processing" to the more professional District Board officers, or even to operatives at the Soviet Republic level. The mass terror that was unleashed in the fight against banditry, which came on top of the endemic abuse of power and the crimes committed by officials, immensely contributed to the continuation of the underground resistance movement and to further exacerbating the already gigantic human losses and devastation brought by war. It should be emphasized that the Soviet security services continually evolved and adapted their modus operandi and organizational structures. Along with the defeat of the anti-Soviet partisan units and the transition of the underground movement to more deeply hidden and less overt conspiratorial methods, the main emphasis was shifted from Internal Troop initiatives to operational activities coordinated by the Anti-Banditry Departments. The system of command and registration was also subject to continuous fine-tuning. Analyzing documents on Soviet security service activities, the tentative thesis might be ventured that Volyn became a sort of peculiar training ground where, without undue losses, the Soviet leadership tested various methods of taking control of territory and subordinating rebellious populations. Total Sovietization was achieved with the help of these operating methods. A highly effective, if extremely bloody and brutal system of dealing with the underground movement, was also thereby created.

Supplement 1. Internal Troop Dispositions in Volyn Oblast.

Volyn Oblast - 9 Rifle Division

October 1944

\begin{tabular}{|l|l|l|l|l|l|}
\hline Name of unit & Base & $\begin{array}{l}\text { Number } \\
\text { of officers }\end{array}$ & $\begin{array}{l}\text { Number } \\
\text { of junior } \\
\text { officers }\end{array}$ & $\begin{array}{l}\text { Number } \\
\text { of soldiers }\end{array}$ & Total \\
\hline $\begin{array}{l}\text { Headquarter of the 9th Division and } \\
\text { specialist sub-units }\end{array}$ & Lutsk & 155 & 167 & 515 & 837 \\
\hline 145th Rifle Regiment headquarters & $\begin{array}{l}\text { Volodymyr- } \\
\text { Volynskyi }\end{array}$ & 51 & 116 & 260 & 427 \\
\hline Company 1 battalion1 regiment 145 & Lokatche & 13 & 28 & 67 & 108 \\
\hline Company 2 battalion1 regiment 145 & Ivanitch & 5 & 22 & 36 & 63 \\
\hline Company 3 battalion1 regiment 145 & Gnojno & 4 & 21 & 31 & 56 \\
\hline
\end{tabular}




\begin{tabular}{|c|c|c|c|c|c|}
\hline Company 4 battalion 1 regiment 145 & Zaturzec & 13 & 39 & 55 & 107 \\
\hline Company 5 battalion 1 regiment 145 & Kysylyn & 5 & 18 & 47 & 70 \\
\hline Company 6 battalion 1 regiment 145 & Kuniczuyev & 6 & 19 & 46 & 71 \\
\hline Company 7 battalion 1 regiment 145 & Kopytow & 4 & 15 & 56 & 75 \\
\hline Company 8 battalion 1 regiment 145 & Sadow & 4 & 14 & 43 & 61 \\
\hline Company 9 battalion 1 regiment 145 & Horochov & 16 & 40 & 89 & 145 \\
\hline $\begin{array}{l}\text { 169th Rifle Regiment headquarter, } \\
\text { specialist sub-units }\end{array}$ & Kolky & 53 & 123 & 300 & 476 \\
\hline Company 1 battalion 1 regiment 169 & Troyanovka & 5 & 21 & 46 & 72 \\
\hline Company 2 battalion 1 regiment 169 & Hradek & 6 & 21 & 46 & 72 \\
\hline Company 3 battalion 1 regiment 169 & Manyevychi & 15 & 28 & 53 & 96 \\
\hline Company 4 battalion 1 regiment 169 & Nowo Ruda & 5 & 20 & 46 & 71 \\
\hline Company 5 battalion 1 regiment 169 & Karasyn & 13 & 35 & 78 & 126 \\
\hline Company 6 battalion 1 regiment 169 & Hryva & 3 & 19 & 37 & 59 \\
\hline Company 7 battalion 1 regiment 169 & Telche & 14 & 34 & 58 & 106 \\
\hline Company 8 battalion 1 regiment 169 & Osnyca & 4 & 22 & 44 & 70 \\
\hline Company 9 battalion 1 regiment 169 & Komarov & 5 & 23 & 39 & 67 \\
\hline $\begin{array}{l}\text { 277th Rifle Regiment headquarter, } \\
\text { specialist sub-units }\end{array}$ & Cuman & 55 & 106 & 247 & 408 \\
\hline $\begin{array}{l}\text { company } 1 \text { and } 2 \text { battalion } 1 \text { regiment } \\
277\end{array}$ & Silno & 5 & 19 & 50 & 74 \\
\hline company 3 battalion 1 regiment 277 & Berescany & 21 & 62 & 148 & 231 \\
\hline company 4 battalion 2 regiment 277 & Cholonievyche & 15 & 40 & 83 & 138 \\
\hline company 5 battalion 2 regiment 277 & Lypno & 5 & 22 & 57 & 84 \\
\hline company 6 battalion 2 regiment 277 & Haraymovka & 6 & 23 & 60 & 89 \\
\hline Riffle battalion 3 in full-force & Schatzk & 27 & 81 & 204 & 312 \\
\hline $\begin{array}{l}\text { Independent battalion-headquarter } \\
189\end{array}$ & $\begin{array}{l}\text { Kamin- } \\
\text { Kashyrskyi }\end{array}$ & 46 & 116 & 278 & 440 \\
\hline Company 2 battalion 189 & Lubashov & 5 & 23 & 48 & 76 \\
\hline Company 3 battalion 189 & Ratne & 4 & 25 & 93 & 122 \\
\hline Squadron of cavalry 1 rifle brigade 18 & Berestechko & 10 & 23 & 93 & 126 \\
\hline Total & & 598 & 1385 & 3302 & 5258 \\
\hline
\end{tabular}

Source: The report on NKVD Internal Troop unit dispositions in the Ukrainian Region. ${ }^{62}$

62 The report on NKVD Internal Troop unit dispositions in the Ukrainian Region GARF z. 9478 op. 1, vol. 642, k. 8-14, [in:] I. Biłas, op. cit., pp. 478-479. 